\title{
Chants, raps and songs: How they enhance language memorisation
}

\author{
Lenga-lengas, raps e canções: como contribuem \\ para melhorar a capacidade de memorização de linguagem
}

Paula Mira Fernandes, Universidade Nova de Lisboa, Portugal (paulacmira@gmail.com)

\begin{abstract}
This action research study aims to show how chants, raps and songs can enhance language memorisation in an English as a Foreign Language classroom and what contributes to it. During my second practicum period I collected data through questionnaires, worksheets, observation grids, a learning journal and students' interviews. These tools helped me understand what is behind chants, raps and songs when teaching a foreign language. I learned that my students loved rhythm, rhymes, repetition, gestures, imitation, body language, intonation and that all of these combined were a booster to language memorisation. There was language appropriation and children were able to recall chants, raps and songs taught in the class through repetition, gestures and rhythm. These contributed to "maximise language pronunciation, intonation, ear training..." (Brewster, Ellis \& Gerard, 2002, p.164). They have beats that contribute to language learning through the repetition of chunks, enhancing memory ability.
\end{abstract}

Keywords: chants, language memorisation, EFT, raps, YL

Resumo: O projeto foi realizado com o intuito de descobrir como é que os aprendentes de inglês memorizam vocabulário e o que contribui para tal. A música, o rap e as lengalengas contêm ritmo. $\mathrm{O}$ ritmo, a repetição, os gestos, a linguagem corporal e a entoação atraem as crianças de uma forma natural e contribuem para aumentar a capacidade de memória dos alunos. Contribuem igualmente para maximizar a pronúncia, a entoação e o treino auditivo (Brewster, Ellis \& Gerard, 2002, p.164). Os professores podem usá-los para criar rotinas, introduzir vocabulário, praticá-lo e revê-lo (Brewster, Ellis \& Gerard, 2002, p.168). Se usarem a música, o rap e as lengalengas com mais frequência contribuirão para o aumento da capacidade de memória dos seus alunos.

Palavras-Chave: capacidade de memorização, crianças, English as a Foreign Language, lengalengas, rap 
During my Master's degree and in my first teaching practice period, I observed a teacher in action, I cotaught with her and then I solo taught with her support. I was fortunate to see how my cooperating teacher had provided exposure to vocabulary and short phrases and encouraged students to participate in oral activities, first through whole group repetition, then in smaller groups, in pairs and individually. Students liked repetition. In fact, I believe repetition motivated students, maybe because they felt safe using short phrases they knew, had learned, practised and could control.

Before starting my second teaching practice, I had decided to do this research project to try to find out how chants, raps and songs contribute to memory enhancement. Chants, chunks and songs have an important role in the national curriculum, as listening and speaking skills are a priority in primary education. "A aprendizagem da língua estrangeira no $1^{\circ}$ ciclo do ensino básico em particular privilegia a oralidade" (Bravo, Cravo \& Duarte, 2014, p.3), which means that the Portuguese curriculum for the $1^{\text {st }}$ cycle of Education in English focuses on oral skills. It also says that the acquisition of lexical structures and chunks are more important than the acquisition of isolated words. Moreover, Aprendizagens Essenciais (Direção-Geral da Educação, 2018) adds that at the end of the $1^{\text {st }}$ cycle students should be able to produce and identify words, short phrases, rhymes, chants and songs. Nevertheless, if we look closely at the majority of course books available in Portugal, we see that most of them have little focus on listening and spoken interaction or production. In fact, their main focus is on reading and writing, which means young learners do not have many opportunities to develop their listening and speaking skills in the classroom. As a consequence of this, students might lower their levels of interest in the language and may find it more and more difficult to speak and interact with their peers. Speaking in a foreign language is an imitation of sounds, repetition accompanied by images, gestures and physical movements and rhythm. When it comes to introducing a foreign language in primary education, learners should be given the opportunities to put into practice all skills, but prioritizing listening and speaking over reading and writing.
Moreover, I wanted to find out how students recalled the language they were taught in the classroom through chants and songs. Is the repetition of words and short phrases provided by chants, raps or songs and accompanied with images, gestures, physical movements and rhythm enough to help students learn? Chants and songs promote language learning as they facilitate memorisation "by creating mental linkages, applying images and sounds, employing action and rhythm and reviewing" (Oxford, 1990, p.18). Rhythm, rhyme, beat, language repetition, movement and gestures, together with chants and songs in the daily routine of a classroom give YLs the motivation they need to be able to participate orally, "even if their level of proficiency is low" (Oxford, 1990, p.18).

\section{Formulaic language, chunks, chants and rap}

According to Wray (2002) "a considerable proportion of our everyday language is 'formulaic" (p.1), that is "predictable in form and idiomatic". This formulaic language, which can also be referred to as a chunk, refers to several words that are usually stored together in our memory and used as a whole. Zimmer (2010) states that children should learn not on a wordby-word basis but in larger lexical chunks as these are "committed to memory". Chunks may consist of simple combinations of two, three or four words (Biber, 1999) that appear together frequently. They can be set phrases with classroom language "Sorry, but I don't understand" or "Can you repeat that, please?" They can be semi-fixed expressions such as "I love chocolate", "It's a beautiful day and I'm not scared" (Rosen, 1989), "In my opinion", "How are you?" or "Know what I mean?" (Nordquist, 2018), and they can be collocations, such as "the big, bad wolf" or "a beautiful sunny day".

Using chunks facilitates communication among native speakers, as Schmitt (2000) explained. It is much easier for a native speaker to use "ready-made chunks" instead of having to think of word selection. For speakers of EFL, chunks are taught as a starter, as a first step to learn a language. Repetition of chunks of language through the use of classroom language, teacher's language, songs, rhymes and the fact that chunks are ready to be used scaffolds non-natives' 
language learning process. It also provides students with a sense of confidence, enabling them to use the language with their peers.

On the contrary, Swan (2006, p.3) argues that the "methodology of the chunking approach will never produce nativelike proficiency" as there are so many variants that a language learner might take years to learn them all. In my opinion, when introducing new vocabulary and learning a foreign language in primary education, chunks are always an asset as they are ready to be used. Teachers should teach students the chunks, plus the appropriate pronunciation through repetition. At this stage, nativelike proficiency is not an issue yet. The fact is chunks are taught in EFL classroom and they are here to stay (Zimmer, 2010). Chants are "stretches of real language put into a rhythmic framework" as Forster (2006, p.64) puts it. Chants are examples of formulaic language as they are comprised of chunks. They involve repetition, rhythm, and musicality of words or sounds. Students just have to use the chant they learned in a rhythmic 'prêt-à-porter' utterance, which means that the chant is ready to be used. Raps are a type of popular music with a "strong beat, in which words are chanted or spoken", according to the online Cambridge Dictionary (CUP, n.d.). In my opinion, they are connected to a sense of rebellion and children do like to be defiant.

Chants, raps and songs stimulate short and long term memory and memory has a crucial role in language comprehension and learning. It stores information about the language used and "uses the data to make sense and communicate" (Eghlidi, Talebinezhad \& Fard, 2017, p.321). These authors say that memory holds verbal information through repetition, which is fundamental for language storage and processing.

\section{How chants, raps and songs help develop lan- guage learning}

It has been proved that music is a powerful teaching tool that fosters language acquisition, retention and production from an early age. "Children love songs", as Brewster, Ellis and Girard (2002, p.162) state. Their "repetitive nature and rhythm" bring a positive effect into the classroom's environment and a feeling of enjoyment, which motivates YLs for the language learning process (Read, 2007, p.184). So, why should teachers not take advantage of such a natural and precious tool?

Chants and songs are natural in any language acquisition process and they play an important role when it comes to learning a foreign language, as they can be used in real life situations. Using them in classroom activities provides opportunities for verbal and non-verbal participation and everyone can join in, allowing tongue-tied learners to practise their oral skills as well. They help "developing phonemic awareness and reinforce the stress, intonation and rhythm of words" (Dias \& Mourão, 2005, p.84). Graham $(1994$, p.5) states that chants provide a "natural way of learning, closer to a nativelike learning environment". Brewster, Ellis and Girard (2002) also refer to songs, rhymes and chants as perfect for learning. Chants and songs facilitate and promote language learning, as they facilitate memorisation "by creating mental linkages, applying images and sounds, employing action and rhythm and reviewing" (Oxford, 1990, p.18). In the daily routine of a classroom they give YLs the motivation they need to be able to participate orally, "even if their level of proficiency is low" (Oliver \& Philp, 2014, p.51). This means that even weaker students may use those bits of language without fear of failure.

Learners are given adequate language models through the use and repetition of chants, raps and songs. This practice enables children to make new phrases and sentences. Their use in the classroom seems to be predictable, familiar and repetitive and YLs know "what they should say or do" (Oliver \& Philp, 2014, p.51). Therefore, it contributes to increase learners' greater motivation and memorisation ability, as they use the language with their peers, that is, useful in real life situations. Chants, raps and songs used in "repeated recycling of vocabulary in different contexts has been shown to foster vocabulary acquisition in YLs" (Kersten, 2015, p.137). If YLs are frequently exposed to learning experiences, they will be able to train their memory and perception skills. The more input they get, the more they will retain. When students hear themselves repeated- 
ly, they acquire language unconsciously. Children will then increase their "lexical items and multi-word structures" and will improve their "speech rhythms, intonation and pronunciation" (Foster, 2006, p.63). YLs must then receive enough exposure through repetition so that chants, raps and songs can be stored in their memory. Providing learners with exposure to natural language will improve their memorisation ability, through drilling and repetition. As Hillyard puts it, "repetition is the key" (2003, p3). In addition, longer strings of words will be easier to memorise (Foster, 2006). At some point, learners will be able to "unpack" and modify these strings to create new phrases.

The rhythm associated to music connects brain and memory. Teachers must take advantage of this brainmemory link "whether the words are chanted or sung" (Graham, 2001, p.9). Furthermore, young children will love anything with music or a beat (Forster, 2006). As they love to play, their ability to sing, pick up sounds, remember melodies and rhythms is strong, so why not use this as an asset and teach them vocabulary items and language items? (Forster, 2006). Murphey believes that "music has the power to engrave itself into our brains" (1992, p.3). As songs work on both our short and our long-term memory, they are adequate tools to be used in the language classroom. As our short-term memory is in fact short, by chanting, rapping or singing students can "take smaller bits of information and combine them into more meaningful, and therefore more memorable, wholes" Murphey (1992, p.3).

Bor (2012) argues that the way we see language patterns and make connections are important for memory and creativity. He claims that chunks aid memory and they can enhance our memory ability through practice, association of ideas, vocabulary connections and mnemonics. Any first or foreign language acquisition process involves the acquisition of memorised sequences of language as "working memory is heavily involved in language acquisition" (Ellis \& Sinclair, 1996, p.234).

According to Wray (2002, p.279), "Large units are most useful for routine interaction", especially with foreign language learners. This means that larger chunks are preferable to smaller ones, as the process to create fluent output is more challenging. However, larger units are more difficult to memorise, as explained above. Myles, Hooper and Mitchell (1998, p.358), after studying French learners, stated that "the use of formulas did indeed facilitate entry into communication and speed up production in early stages". Regarding language memorisation, Conesa and Rubio (2015) give the example of teaching the alphabet to children. Their study concludes that children learned it faster and hence memorised it better when teachers sang along with them. They also mention the fact that children are more motivated and stimulated by authentic materials, such as realia. Chants, raps and songs are authentic language, and most course books already incorporate these. Bilbrough (2011) adds that memory is "the glue that binds us to the world of language" (p1). Foster (2006) concludes by saying that children need to make use of their memory to make and complete sentences or phrases.

Read (2005) states that the best way to "maximize the benefits of using chants and songs" (p.183) in lessons is in an integrated way. The use of a range of skills in a sequence of different activities enhances language transfer into other contexts in a safe way. This brings confidence to YLs.

\section{How chants, raps and songs can be used in the classroom}

Language teachers should make use of chants, raps or songs as part of their classroom routine, i.e., to start or finish their lessons, to illustrate and introduce topics, to add variety or a change of pace, to introduce new vocabulary or to recycle already known language. Forster considers chants and songs of great value when teaching long stretches of real language, especially when related to "classroom functions, daily routines or communicative situations" (2006, p.65). She considers two aspects when presenting chants and songs to YLs: the students' age and the relevance of the chant or song. Moreover, to attain a good result from the very first contact with the language she presents some guidelines. First, to present the chant orally, little by little in every lesson, always reviewing and revisiting previous vocabulary and learned chants 
(Foster, 2006), raps and songs. To revisit language is an opportunity to "review and build confidence" (Foster, 2006, p.65). Second, to use creativity to be able to create new chants. All elements recommended by the Total Physical Response approach to teaching should be used. Clapping, tapping, snapping fingers, making body gestures and whistling contribute to enhance memorisation ability (Mejzini, 2016) and are, therefore, important tools to promote improvement in English speech, rhythms, intonation and pronunciation and a facilitation of memorisation of longer chunks.

\section{My Action Research}

The main goal of this project was to answer the questions "How can I improve my students' learning ability, using chants, raps and songs?" and "How can students memorise language, through chants, raps and songs?" In order to find the answers to my research questions, I set up an action research plan. This involved "taking a self-reflective, critical and systematic approach to exploring your own teaching contexts" (Burns, 2010, p.2).

I followed the cluster's orientations and tried to find a chant, rap or song for each topic to be taught. I planned each chant, rap and song I would be teaching, I taught set phrases and semi-fixed expressions, put the plan into action and observed the results. I reflected on the results and adapted the plan according to the feedback received from the students. I revised, adapted and planned the following steps. This method helped me to reflect on my teaching practice and on my students' learning process and to be critical about my teaching, my materials, activities and findings. During this period, I collected data to help me answer my research questions.

I informed the cluster's director of the purpose of my study, asking for her permission to conduct the study. Second, a letter of consent written in Portuguese was sent to parents, explaining the aim and the length of the project, as well as the methodology regarding data collection. Third, students were also asked for their consent. I explained why it was important for them to participate and that they could choose not to participate at any point. 27 students agreed and signed their consent forms. After receiving positive feedback from the school cluster, I started my practicum on the 4th October of 2018 and taught 18 lessons.

\section{How chants, raps and songs were taught}

Activities such as speaking, listening, reading and role-playing were carried out, either to introduce or to practise chants, raps or songs.

a) The alphabet chant. To introduce the letters of the alphabet I brainstormed them first, in case some students already knew them. I wrote each letter on the board, a line for each verse of the chant I wanted to teach the students. Students and I grouped the letters according to their sounds. The letters were taught as a chant. I chanted the first 7 letters of the alphabet and students repeated them. I chanted the following 9, 6 and 4 letters and students repeated them, first as a whole group and then in rows. In the following lesson, groups of students said the chant for others to repeat. Students with special educational needs and weaker ones volunteered too. Every student participated in the alphabet chant.

b) How do you spell your name? In October, students were struggling to ask the question 'How do you spell your name?'. The number of words might have been an issue and "do" was always missing, maybe because it had no correspondence in their L1 question structure. I introduced a rap, accompanied by intonation, gestures, adequate rhythm, rebel moves, crossing my arms and saying 'Huh?' at the end. Students wanted to participate and repeat the chant. The chant 'How do you spell your name?' had been introduced effectively.

c) The Halloween story. Based on Carolyn Graham's video (2018), I introduced the four characters of the story, I explained what they did and drilled the story. At the end of the lesson, students were able to chant the story by themselves, through repetition and gestures.

d) How old are you? This question was not planned to be taught as a chant. As a matter of fact, students were struggling to ask the question correctly and they kept asking 'How are you?' instead. I turned it into 2 chunks (How old - are you?), and added rhythm and 
repetition, gestures and body language to help students say their age (numbers 1 to 10).

e) Days of the Week. The students heard the song "Days of the Week" (Martin \& Rose, 2017) twice and practised the days of the week in a memory game on the board. The aim was not to learn the song. The question 'What's your favourite day of the week?' was divided into two chunks to ease the learning process and was written on the board separately 'What's your favourite - day of the week?

\section{Data collection and Research tools}

To increase the quality and rigour of the research, I tried to collect data through a significant range of observational and non-observational tools and I used both quantitative and qualitative data. A learning journal, observation grids, questionnaires, interviews and worksheets were the research tools used to strengthen triangulation. The questionnaires and worksheets were carried out anonymously.

I used a learning journal to reflect on my teaching and on my students' learning with chants, raps and songs. I collected thoughts, reflections on my lessons, on my students' learning and their comments. I took notes of what had gone well or should be corrected and avoided next time, what I could have done differently, which activities and stages had taken longer than expected and why, my students' comments, struggles, learning, reactions and behaviour. I used my learning journal to focus on what I could repeat or needed to improve in the following lesson. I collected moments to reflect on and I knew exactly when and in what circumstances they happened. In the spare pages of my journal I wrote some examples of good practices or important quotations to focus on, concerning the difficulties I faced during my practicum.

Observation grids were used to keep track of the students' level of participation, difficulty in using the language, task achievements and language memorisation. The purpose was also to have a different perspective, my peers' perspective on a small group of 4 children. My cooperating teacher and my peers, who came to observe me separately in November and in December, were asked to focus on a small group of students during chant activities. The observation grids were filled in during 3 lessons, by a total of 4 teachers. While observing, teachers were focusing on whether each student had shown difficulties in saying the letters, used the language with long pauses or used the language effectively, without long pauses. Were YLs able to say the alphabet chant? Had YLs showed difficulties in achieving the task, i.e., saying the chant, if they carried out the task, but with some difficulty or carried out the task successfully and with relative ease and whether children had memorised the language structure and chant with difficulty or apparent ease.

I used worksheets to verify whether students were able to remember and had learned chants, raps and songs taught previously. After oral practice, they had to sequence verses and reorder words to make sentences related to chants, raps and songs.

I used anonymous questionnaires to find out whether students felt chants, raps and songs had been important to memorise the language taught and to know what they did to remember the vocabulary or structure taught. Questionnaires were completed anonymously, and I asked the students to be truthful. After oral revision of each topic, all students filled in the questionnaires in December 2018 and in January 2019. I used closed questions in the first questionnaires and students were asked to colour the appropriate face, according to their answers to the questions. I used a multiple-choice questionnaire in January with only one possible option, as I wanted students to choose what the most important learning aspect had been. The results were analysed as percentages related to the YLs' perspective of how important those instruments were for their learning process.

I interviewed eleven randomly selected students individually in January. The interviews were conducted in Portuguese. They were not recorded. The aim was to gather evidence on how YLs thought they remembered chants, raps and songs taught in the classroom and what they did to remember them. I wanted to know their opinion on what made memorisation possible and what could have contributed to vocabulary memorisation. During the interview, all YLs were asked to sing parts of chants, raps and songs they had been taught. They were also asked how they memo- 
rised the vocabulary and structures taught in the classroom, how they felt and if they enjoyed learning with chants, raps and songs.

\section{Discussion and Conclusion}

The question "How can I improve my students' learning ability using chants, raps and songs?" was answered through the activities done with chants, raps and songs. The results show that children reacted very positively to them. The students were always very receptive, motivated and ready to participate and the questionnaires show that they thought that chants and songs helped them memorise the vocabulary learned in class. This happened in such a way that they showed language appropriation, turning questions into chants and raps. Concerning the research question "How can students memorise language?" results from the final questionnaire show that most students resorted to the chants, raps and songs to access the language they needed. Students highlighted the fact that chants, raps and songs were kept in their memory and that they enhanced their English ability.

In the interviews carried out in January 2019, 11 randomly chosen students were asked 5 questions related to the action research question "How are students able to recall chants and songs learned in the classroom?" All students were unanimous in stating that chants, raps and songs helped them memorise vocabulary because they had gestures, rhythm, repetition and they were fun.

Observation grids were filled in by my cooperating teacher, observing peers and by myself. They helped me observe who was on task and focused, who participated or not, who struggled more, who did not use English during activities, who was able to say the chant, rap or song, and who remembered the chant using body language. They were of extreme importance, as they helped me keep track on the students' progress.

The worksheets show that, even if writing was not considered for this action research project, half of the students succeeded in reordering weekdays and writing down the sentence and the question. Students had previously transformed phrases and semi fixed expressions into chants. As half of them did not succeed in reordering words to make sentences, I wonder if they were exposed enough to the written form. In my opinion, learning with chants, raps and songs may not be enough in EFL. They should always be complemented with reading and writing. One student mentioned "it is important to learn with and without raps, because raps are good to memorise vocabulary for those who like raps, but for the ones who do not like them it might be good to learn differently".

Comparing the data collected from my learning journal with that from students' direct observation, I believe that the most important feature were the "raps, due to the 'I'm bad', rebel feeling behind gestures and rhythm", and children liked being a part of that. Nonetheless, not all the moves were rap moves. They were physical responses sometimes. As mentioned above, during this project and in two different occasions, YLs showed language appropriation, as they spontaneously transformed phrases and semi fixed expressions into raps.

There is no doubt about the students' engagement, motivation and interest towards EFL and the theme. Raps, chants and songs are important to engage students, to make them more at ease and comfortable to learn and to create a healthy learning environment. I believe this approach may be useful for tongue-tied YLs, as it seems to help shy students. Students did not feel nervous; on the contrary, even students with special educational needs wanted to go up front and show their colleagues they could do the speaking task. And they did. They felt important and valued by their peers. Nevertheless, we need to take students further and provide them with varied tools to work with. I am afraid I was too focused on listening and speaking skills and I should have given students more written material, as a way of confirming and consolidating what they had learned. The results from the worksheets would certainly look different.

This action research project, in conjunction with my practicum, was important for me, as a teacher, because I developed teaching skills I would not have gained otherwise. They made me reflect about my teaching, on illustrating, modelling and presenting, rather than repeating myself. I now have more doubts than ever before, which means I am questioning my- 
self. They made me wonder whether the students had learned, how they had learned and how I knew they had; if the students had gained listening, speaking, reading and writing skills in each lesson; if the students had worked in a big group, small groups, in pairs or individually. They made me consider that a student-centred lesson is much more interesting to students than a teacher-centred one. They made me think how rebel moves may affect students' attitudes and how I can make them constructive, preventing students from being disruptive. They made me realise that effective classroom management is achieved through relationships, routines, rules, rights, responsibilities, rhythm, respect and rewards.

The purpose of this action research project was to answer the questions "How can I improve my students' learning ability using chants, raps and songs?" and "How can students memorise chants, raps and songs?" Children love songs as Brewster, Ellis and Girard (2002, p.162) stated. Their "repetitive nature and rhythm" bring a positive effect into the classroom's environment and a feeling of enjoyment, which motivates YLs. Learners were always very receptive, motivated and ready to participate. They even transformed questions into chants and raps. Rhythm, rhymes, repetition, gestures, imitation, body language and intonation combined were an aid to language memorisation. Chants, raps and songs contributed to short and long term memory and memory has a crucial role in language comprehension and learning. It holds verbal information through repetition, which is fundamental for language storage and processing. Most students resorted to the chants, raps and songs to access the language they needed. Chants, raps and songs were kept in the students' memory and they enhanced their learning ability. The repetition of words and short phrases provided by chants, raps or songs, accompanied with images, gestures, physical movements and rhythm were not enough to help students memorise language. They promoted language learning, as they facilitated memorisation through the creation of mental linkages. However, there is much more to be done when learning a language. During the interviews one of the students said it was important to learn with chants, raps and songs, but also without them because if some students liked learning that way, others might not. Studying and comparing both ways of learning could be a matter for future research.

\section{Final conclusion}

The use of chants, raps and songs contributed to language memorisation. In my opinion, the major finding of this action research project was that chants, raps and songs contributed to increase the students' levels of interest in English. YLs showed listening and repeating skills, through repetition, gestures and body language, rhythm, rhymes, imitation and intonation. However, according to the data gathered throughout the worksheets done after drilling exercises, students did not know how to write what they had been saying or to order words to make sentences. The repetition of words and short phrases provided by chants, raps and songs proved not to be enough to learn the language, although they promoted language memorisation. Despite the fact YLs knew the language taught orally, they were incapable of ordering it to make sentences. 


\section{References}

Biber, D., Johansson, S., Leech, G., Conrad, S., \& Finegan, E. (1999). Longman grammar of spoken and written English. Harlow: Pearson Education.

Bilbrough, N. (2011). Memory activities in language learning. Cambridge: Cambridge University Press.

Bor, D. (2012). The ravenous brain: How the new science of consciousness explains our insatiable search for meaning. New York: Basic Books.

Brewster, J., Ellis, G., \& Girard, D. (2002). The primary English teacher's guide. London: Longman.

Burns, A. (2010). Doing action research in English language teaching: A guide for practitioners. Abingdon: Routledge.

Cambridge University Press (n.d.) Cambridge Online Dictionary. Retrieved from https:// dictionary.cambridge.org/dictionary/english/rap

Conesa, I., \& Rubio, A. (2015). The use of rhymes and songs in the teaching of English in primary education. Docencia e Investigación, 25(2), 83-101.

Cravo, A., Bravo, C., \& Duarte, E. (2014). Metas curriculares de inglês ensino básico: $1^{\circ}$ ciclo. Lisboa: Ministério da Educação e Ciência.

Dias, A., \& Mourão, S. (2005). Inglês no $1^{\circ}$ ciclo. Práticas partilhadas. Porto: Edições ASA.

Direção-Geral da Educação. (2018). Aprendizagens essenciais. Lisboa: Ministério da Educação e Ciência.

Eghlidi, M., Talebinezhad, M., \& Fard, Z. (2017). Psycholinguistic perspectives and contributions of ELL and ELT. Journal of Applied Linguistics and Language Research, 4, 317-335.

Ellis, N., \& Sinclair, S. (1996). Working memory in the acquisition of vocabulary and syntax: Putting language in good order. The Quarterly Journal of Experimental Psychology, 49(1), 234-250.

Forster, E. (2006). The value of songs and chants for young learners. Encuentro-Journal of Research and Innovation in the Language Classroom, 16, 63-68.

Graham, C. (2006). Creating chants and songs. Oxford: Oxford University Press.

Graham, C. (2018). Carolyn Graham Jazz chants with children in Japan. Retrieved from https:// www.youtube.com/watch?v=LvEYkX1pnXo

Hillyard, S. (2013). Varied repetition of songs in EFL kindergarten contexts. Young Learner and Teenager Special Interest Group Publication, 19-22.

Kersten, S. (2015). Language development in young learners: The role of formulaic language. In Janice Bland, (Ed.), Teaching English to Young Learners: Critical Issues in Language Teaching with 3-12-year-old, 129145. London: Bloomsbury Academic.

Lindstromberg, S., \& Boers, F. (2008). Teaching chunks of language: From noticing to remembering. London: Helbling Languages.

Martin \& Rose Music. (2017). Days of the week. Retrieved from https://www.youtube.com/watch?v=8GKmCQOy88Y

Mejzinii, M. (2016). Teaching children through songs, chants and rhymes. European Journal of English Language Teaching, 1(2), 104-113.

Murphey, T. (1992). Music and song. Oxford: Oxford University Press.

Myles, F., Hooper, J., \& Mitchell, R. (1998). Rote or rule? Exploring the role of formulaic language in classroom foreign language learning. Language Learning, 48(3), 323-363. 
Nordquist, R. (2018). Chunk (language acquisition). ThoughtCo. Retrieved from https://www.thoughtco.com/ chunk-language-acquisition-1689841

Oliver, R., \& Philp, J. (2014). Focus on oral interaction. Oxford: Oxford University Press.

Oxford, R. (1990). Language learning strategies: What every teacher should know. New York: Newbury House / Harper \& Row.

Read, C. (2007). 500 activities for the primary classroom. Oxford: Macmillan Publishers Limited.

Rosen, M. (1989). Michael Rosen performs We're Going on a Bear Hunt. Retrieved from https:// www.youtube.com/watch?v=0gyl6ykDwds

Schmitt, N. (2000). Key concepts in ELT: Lexical chunks. ELT Journal, 54(4), 400-401.

Slattery, M., \& Willis, J. (2001). English for primary teachers - A handbook of activities \& classroom language. Oxford: Oxford University Press.

Swan, M. (2006). Chunks in the classroom: Let's not go overboard. Teacher Trainer, 20(3), 5-6.

Wray, A. (2002). Formulaic language and lexicon. Cambridge: Cambridge University Press.

Zimmer, B. (2010). Chunking. The New York Times Magazine. Retrieved from https://www.nytimes.com/2010/09/19/ magazine/19FOB-OnLanguage-Zimmer.html 